\title{
Gender Stratification by Variants /n/ and / $/$ / in Lahore city: The Labovian Paradigm
}

\author{
Zafar Iqbal Bhatti ${ }^{1}$, Anila Akbar ${ }^{1}$, Zarmina $\operatorname{Khan}^{1} \&$ Saadia Ishfaq ${ }^{1}$ \\ ${ }^{1}$ University of Management and Technology, Lahore, Pakistan \\ Correspondence: Zafar Iqbal Bhatti, University of Management and Technology, Lahore, Pakistan. E-mail: \\ ravianz902@gmail.com
}

Received: December 11, 2019 Accepted: January 15, 2020 Online Published: February 13, 2020

doi:10.5539/ijel.v10n2p294 URL: https://doi.org/10.5539/ijel.v10n2p294

\begin{abstract}
The study is an investigation of language within the social context of the community in which it is spoken, carried out in 2019 in a region with a particular linguistic background, Lahore, the capital of Punjab, Pakistan. This research investigates the stratification of nasal variants $/ \mathrm{n} /$ and $/ \mathrm{n} /$ in the Lahore city, relating parameter of gender. This research was intended to determine the male and female use of the nasal variants $/ \mathrm{n} / \mathrm{and} / \mathrm{n} /$, indicates that gender-based differences in male/female linguistic behavior in the Lahore speech community. A structured interview was administered in order to examine this issue of social stratification by language. In this regard, this study becomes a Labovian methodological replica in the present context. The results show several statistically significant differences in linguistic usage among different groups of people residing in Lahore city. This research was intended to determine whether men and women were different with respect to the use of nasal variants $/ \mathrm{n} / \mathrm{and} / \mathrm{n}$. Moreover, an examination of the social class and regionality (urban/rural) is also under consideration in the present research.
\end{abstract}

Keywords: linguistic variant, gender, stratification, education, social class

\section{Introduction}

This research was intended to determine whether men and women were different with respect to the use of nasal variants $/ \mathrm{n} /$ and $/ \tilde{\mathrm{r}} /$. To conduct the study, R. Lakoff's (1975) and Labov's (1960) ideas concerning linguistic differences between males and females were taken into account. This research investigates and examines the stratification of nasal variants $/ \mathrm{n} /$ and $/ \tilde{\mathrm{f}} /$ in the Lahore city, relating social parameter of gender. The study is concerned with presence or absence of $/ \tilde{\mathrm{t}} / \mathrm{a}$ retroflex nasal flap that frequently occurs in the speech communities of various parts of rural and urban Punjab.

Variant $/ \tilde{\mathrm{t}} /$ is socially stigmatized in all of the speech community in Lahore, it has been studied to date, with subjective evaluation tests and self-report tests supporting this view. For example, some interviews conducted in various areas of Lahore and found that the standard (n) variant produced by educated women and conscious speakers, the lower he or she was rated who used this stigmatized variant in these areas.

The following study is a sociolinguistic study carried out in 2017 in Lahore, Pakistan. This is a region with a particular sociolinguistic context which stems from the area's sociolinguistic, political and economic history. This study is an investigation of language within the social context of the community in which it is spoken. The focus of this study is to know the objective pattern of language usage in different social contexts in a speech community. More specifically, this examines the relationship between linguistic and gender factors and how men and women distinguish themselves from one another in a whole range of social behaviors including the type of language they use. In this regard, Lakoff's (1975) ideas concerning linguistic differences between males and females were taken into account for justifying her claim concerning the standard linguistic form than menfolk in a speech community. 


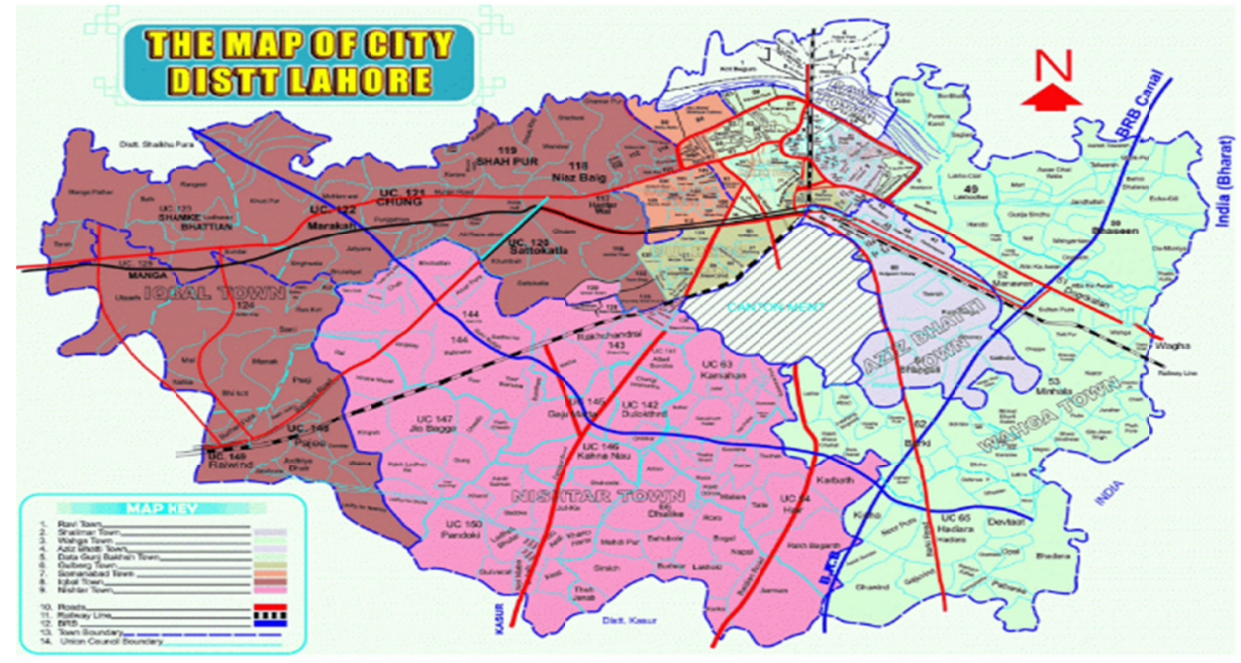

Figure 1. Comprehensive map of capital of Punjab province, Lahore

\section{Literature Review}

Louis Gauchat (1905) observed women in each group tended to use the innovative variants more than men in village of Charmey (Switzerland). "Sociolinguistic variables," Gumperz (1992) wrote, "are themselves constitutive of social reality and can be treated as part of a more general class of indexical signs which guide and channel the interpretation of intent." For example, in the case of $-n$ variable, Shuy et al. (1967) showed that '-in' was more frequently used by lower status groups than higher status ones, Fischer (1958) showed that boys tended to use more '-in' than girls and that differences also related to speaker personality type (aggressive vs. cooperative) and mood (tense vs. relaxed).

In the present research, the technique of auditory analysis has been employed for researching the phenomenon of linguistic variation. In this context, Trudgill's (1974) research in Norwich, showed the results of the correlation of social class, speaker sex and the use of non-standard [n] variants of unstressed '-ing' suffixes. Within each social class group, women consistently used less of the non-standard pronunciation than men.

Trudgill (1972) found a consistent pattern of under-reporting for men and over-reporting for women that reinforced the notion of covert prestige of vernacular forms. His (1972) early work on Norwich English shows that some speakers recognize and overtly talk about one variant as being 'better' than another; furthermore, they claim to use the 'better' form, but in fact do not.

According to Trudgill (1974), women belonging to different social strata in order to demonstrate their social status use more prestigious pronunciation forms and grammatical constructions. Men's speech is characterized by a great number of deviations from standard language due to their masculine type of behavior (Trudgill, 1974). Individual speech code develops under the influence of a number of factors, for instance social, cultural, and economic.

Haeri (1991) undertook the study of the colloquial Arabic of Cairo with a sample of 100 speakers located from a series of networks through friends and extended contacts. The sample was stratified by gender and four social classes; the upper class was the group most strongly oriented towards western culture. One part of Haeri's study was aimed at the stable sociolinguistic variable Qaf, where men consistently used more of the traditional uvular stop. Haeri showed that this use was essentially a series of lexical borrowings from classical Arabic rather than inherent variation in Egyptian Arabic. She also studied a new change in progress, palatalization of apical stops by following high vowels, and found that the leaders of linguistic change were intrepid women who resisted the pressures to conform to traditional social constraints. Abdel-Jawad (1986) found that women used less of the classical uvular variants than men, and more of the modern urban glottal stop, at all educational levels.

\section{Problem Statement}

In this research, the researcher has tried to explore the pattern of the usage of variant $/ \tilde{\mathrm{t}} /$ (retro flex nasal flap) between genders, for the sake of confirming either the variable ( $\mathfrak{\mathfrak { C }})$ is the gender differentiator among social classes, age and region or not. 


\section{Research Questions}

(1) Is there any significant difference between the groups (male \& female) under study on the use of retroflex nasal flap $/ \tilde{\mathrm{t}} /$ ?

(2) Is there any significant difference between educated and uneducated women on the use of $\tilde{\mathrm{r}} /$ ?

(3) Is there any significant gender difference among social groups (low, middle $\&$ high) on the use of $\tilde{\mathrm{r}} /$ ?

(4) Is there any significant difference between urban and rural women on the use of $/ \tilde{\hat{t}} /$ ?

\section{Methodology}

There were 10 questions divided into two parts in this way, 6 questions representing independent variables were the profile questions about the subjects. The content of the interviews covers very specific phonetic information regarding their pronunciation of nasal variants. The main items of demographic information and relevant background data that is very much essential for the linguistic research. These demographic features include gender. The structured interview was administered for eliciting desired data. In this connection, some questions are prepared in advance in the form of MCQs with only two choices. The responses were keenly recorded for further analysis. During the interview the participants were unaware that the researcher was interested in their speech patterns especially in their pronunciation of $/ \mathrm{n} /$ in the word final and postvocalic position (occurring immediately after a vowel), rather than the content of the interviews. All 72 subjects were selected by random stratified sampling representing all dependent variables including gender.

\subsection{Sample \& Sampling Technique}

In order to draw the desired sample from the population, stratified random sampling technique was applied for this study. The sample was selected in such a way that the identified subgroups (e.g., urban vs. non-urban speakers) in the population were adequately represented in the sample. For subgroup comparison, equal-sized samples from each of the subgroups were selected. The stratification of the sample will be based on age, sex, region, education and social class membership. The sample would be further divided into three age groups (15$30,30-45, \& 45-60)$.

A Sample consisted of 72 Subjects and the composition of the sample was as follows

Table 1. Grouping of the subjects in the sample

\begin{tabular}{lllllll}
\hline Sample Group & Social Class & Region & Education & Age & Gender & $N$ \\
\hline 1 & Upper & Urban / Non-Urban & Literate & $15-30$ & Male & 12 \\
& & & Illiterate & $30-45$ & Female & 12 \\
& & & $45-60$ & & \\
2 & \multirow{3}{*}{ Middle } & Urban / Non- Urban & Literate & $15-30$ & Male & 12 \\
& & & Illiterate & $30-45$ & Female & 12 \\
& & & $45-60$ & & \\
3 & \multirow{3}{*}{ Lower } & Urban / Non- Urban & Literate & $15-30$ & Male & 12 \\
& & & Illiterate & $30-45$ & Female & 12 \\
& & & $45-60$ & & \\
\hline
\end{tabular}

\section{Data Analysis}

The data were coded and turned into numerical data as appropriate. It was then submitted to statistical analysis using SPSS (Statistical Package for Social Sciences). The statistical techniques included frequencies, t-test, and analysis of variance. The choice of statistical techniques was based on the research question to be answered.

\subsection{Quantification of Data}

It is very important step in calculation for the analysis. The basic information and the simple characteristics were tabulated and calculated the frequencies and percentages and analyzed.

Scoring scheme of the study:

Scoring is necessary for the measurement of the variables.

\begin{tabular}{lll}
\hline \multicolumn{2}{l}{ Gender of respondents } \\
\hline Gender & Male & Female \\
Coding & 1 & 2 \\
\hline
\end{tabular}


Question No 1, 2, 3, 4, 5, 6, 7, 8, 9, 10, 11, 12, 13

\begin{tabular}{|c|c|c|}
\hline & Retroflex Nasal Flap (RNF)/ $/{ }^{\prime}$ & Nasal Variant (NV) /n/ \\
\hline Coding & 1 & 2 \\
\hline
\end{tabular}

\subsection{The Chi-Square Test}

The chi-square shows the association between the two variables that are under investigation. It evaluates the degree of dependency by comparing the frequencies. The data in the chi-square indicates whether the hypothesis can be accepted or rejected.

\section{General Procedure for testing Hypothesis:}

1) $H_{o}=$ The two variables of classification are not associated

2) $H_{1}=$ The two variables of classification are associated

3) Level of significance: $\alpha=0.05$

4) Test Statistics:

$$
\chi^{2}=\sum_{i}^{r} \sum_{j}^{c} \frac{\left(o_{i j}-e_{i j}\right)^{2}}{e_{i j}}
$$

\subsection{Section Conclusion}

This chapter has discussed the research methodology used in the current study. The present study intends to explore the distinction between $/ \mathrm{n} /$ and $/ \tilde{\mathrm{l}} /$ for comprehending demarcating boundaries between gender. A pure quantitative approach has been employed by the researcher like Labov (1966) which was suited to find answers to the research hypotheses. The phonetic data was gathered by conducting a structured interview (question-answer form). The credibility of the data was established by the careful development of the instruments and by rigorous approach to data analysis.

\section{Data Analysis}

Statistical analysis of the data collected in the structured interviews stage revealed significant differences between male and female. There are statistically significant differences in these samples.

\subsection{General Findings}

Table 2. Distribution of respondent with respect to gender they belong

\begin{tabular}{llll}
\hline & & Frequency & Percent \\
\hline Valid & Male & 36 & 50.0 \\
& Female & 36 & 50.0 \\
& Total & 72 & 100.0 \\
\hline
\end{tabular}

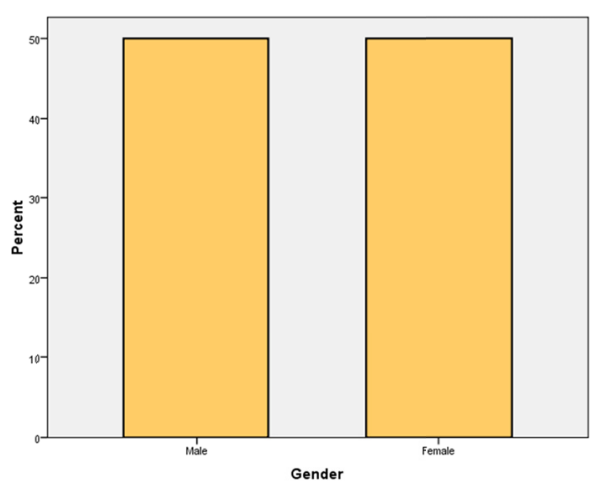

Figure 2. Bar chart shows the percentage of respondents $(\mathrm{M} / \mathrm{F})$

\section{Explanation:}

The above chart shows that in the sample of 72 respondents there are $50 \%$ male respondents and $50 \%$ female respondents. 
Statistical Test

\section{Question 1}

\begin{tabular}{|c|c|c|c|c|}
\hline \multicolumn{5}{|l|}{ Crosstab } \\
\hline \multicolumn{5}{|l|}{ Count } \\
\hline & & \multicolumn{2}{|c|}{ Gender } & \multirow[t]{2}{*}{ Total } \\
\hline & & Male & Female & \\
\hline \multirow[t]{2}{*}{ Which of these two are used for producing electricity? } & RNF & 21 & 18 & 39 \\
\hline & NV & 14 & 18 & 32 \\
\hline Total & & 35 & 36 & 71 \\
\hline
\end{tabular}

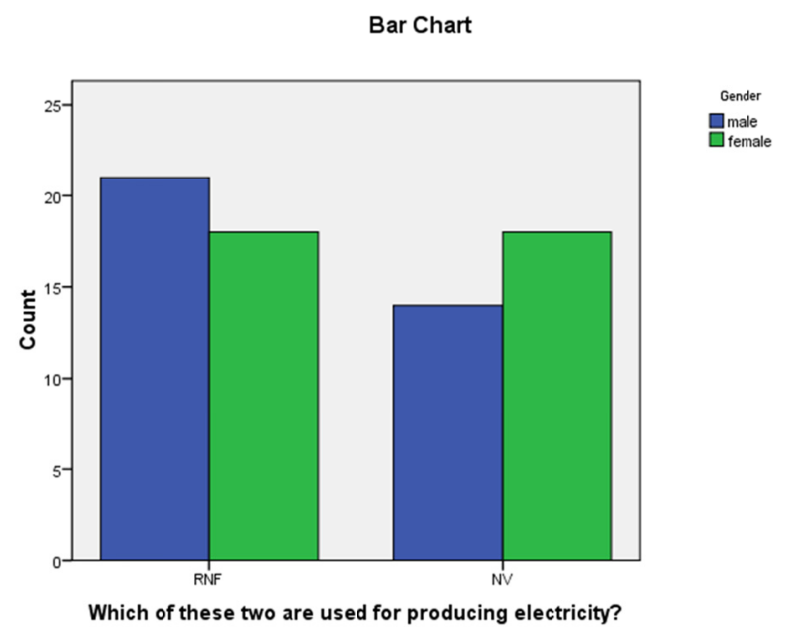

Figure 3. Bar chart shows the percentage of responses of both respondents (M/F)

1) $H_{o}=$ There is no association between the two variables.

$H_{1}=$ There is association between the two variables.

2) Level of significance: $\alpha=0.05$

3) Test Statistics:

$$
\chi^{2}=\sum_{i}^{r} \sum_{j}^{c} \frac{\left(o_{i j}-e_{i j}\right)^{2}}{e_{i j}}
$$

With degrees of freedom (r-1) (c-1)

4) Calculation:

\begin{tabular}{llll}
\hline & Value & df & Asymp. Sig. (2-sided) \\
\hline Pearson Chi-Square & 0.717 & 1 & 0.397 \\
\hline
\end{tabular}

$$
\chi^{2}=0.717
$$

5) Critical region:

Probability value $>$ significance level $(\alpha)$

6) Conclusion:

The probability value is greater than level of significance so we accept null hypothesis $H_{o}$ and conclude that there is not sufficient evidence to indicate that there is association between the two variables. 
Question 2

\begin{tabular}{lllll}
\hline Which aspect of man is the favorite in life?* Gender & & \\
\hline Count & & & & \\
& & Gender & & Total \\
\cline { 2 - 4 } & & Male & Female & \\
Which aspect of man is the favourite in life? & RNF & 12 & 13 & 25 \\
& NV & 24 & 22 & 46 \\
Total & & 36 & 35 & 71 \\
\hline
\end{tabular}

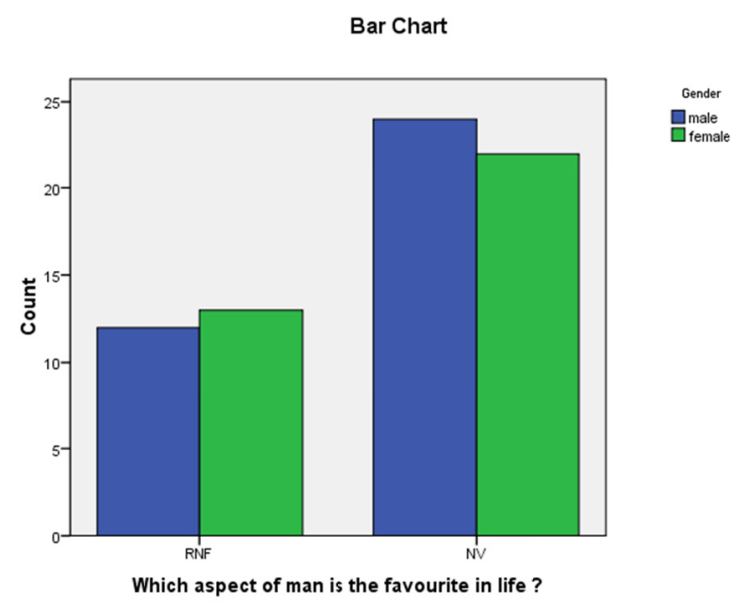

Figure 4. Bar chart shows the percentage of responses of both respondents (M/F)

1) $H_{o}=$ There is no association between the two variables.

$H_{1}=$ There is association between the two variables.

2) Level of significance: $\alpha=0.05$

3) Test Statistics:

$$
\chi^{2}=\sum_{i}^{r} \sum_{j}^{c} \frac{\left(o_{i j}-e_{i j}\right)^{2}}{e_{i j}}
$$

With degrees of freedom (r-1) (c-1)

4) Calculation:

\begin{tabular}{llll}
\hline & Value & df & Asymp. Sig. (2-sided) \\
\hline Pearson Chi-Square & 0.113 & 1 & 0.737
\end{tabular}

$\chi^{2}=0.113$

5) Critical region:

Probability value $>$ significance level $(\alpha)$

6) Conclusion:

As our probability value is greater than level of significance so we are unable to reject our null hypothesis $H_{o}$ and we conclude that there is not sufficient evidence which show association between the two variables. 
Question 3

\begin{tabular}{|c|c|c|c|c|}
\hline \multicolumn{5}{|l|}{ Which is more essential thing for a tired person? } \\
\hline \multicolumn{5}{|l|}{ Count } \\
\hline & & \multicolumn{2}{|c|}{ Gender } & \multirow[t]{2}{*}{ Total } \\
\hline & & Male & Female & \\
\hline \multirow[t]{2}{*}{ Which is more essential thing for a tired person? } & RNF & 11 & 9 & 20 \\
\hline & NV & 25 & 27 & 52 \\
\hline Total & & 36 & 36 & 72 \\
\hline
\end{tabular}

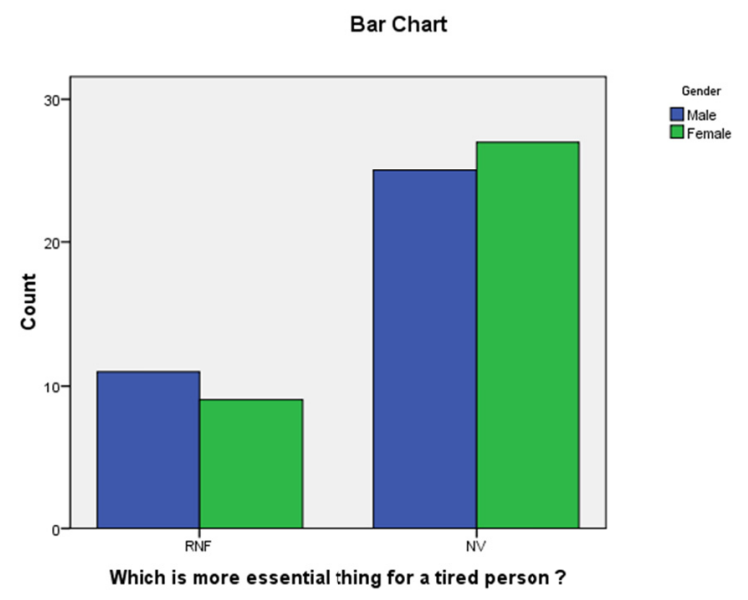

Figure 5. Bar chart shows the percentage of responses of both respondents (M/F)

1) $H_{o}=$ There is no association between the two variables.

$H_{1}=$ There is association between the two variables.

2) Level of significance: $\alpha=0.05$

3) Test Statistics:

$$
\chi^{2}=\sum_{i}^{r} \sum_{j}^{c} \frac{\left(o_{i j}-e_{i j}\right)^{2}}{e_{i j}}
$$

With degrees of freedom (r-1) (c-1)

4) Calculation

\begin{tabular}{llll}
\hline & Value & df & Asymp. Sig. (2-sided) \\
\hline Pearson Chi-Square & 0.277 & 1 & 0.599
\end{tabular}

$\chi^{2}=0.277$

5) Critical region:

Probability value $>$ significance level $(\alpha)$

6) Conclusion:

As our probability value is greater than level of significance so we accept null hypothesis $H_{o}$. On the basis of evidence, we may conclude that there is no association between the two variables. 
Question 4

\begin{tabular}{lllll}
\hline \multicolumn{3}{l}{ What is the name for a person who is blind from one eye? } \\
\hline \multicolumn{4}{l}{ Count } & \multicolumn{3}{l}{} & \multirow{2}{*}{ Gender } & & \\
\cline { 2 - 4 } & & Male & Female & \\
\hline What is the name for a person & RNF & 20 & 14 & 34 \\
who is blind from one eye? & NV & 16 & 21 & 37 \\
Total & & 36 & 35 & 71 \\
\hline
\end{tabular}

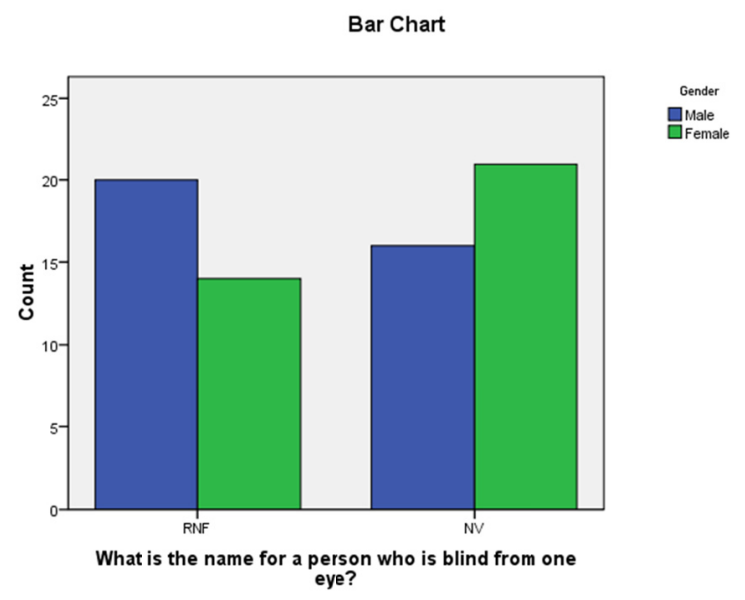

Figure 6. Bar chart shows the percentage of responses of both respondents (M/F)

1) $H_{o}=$ There is no association between the two variables.

$H_{1}=$ There is association between the two variables.

2) Level of significance: $\alpha=0.05$

3) Test Statistics:

$$
\chi^{2}=\sum_{i}^{r} \sum_{j}^{c} \frac{\left(o_{i j}-e_{i j}\right)^{2}}{e_{i j}}
$$

With degrees of freedom (r-1) (c-1)

4) Calculation:

$\chi^{2}=1.721$

\begin{tabular}{llll}
\hline & Value & df & Asymp. Sig. (2-sided) \\
\hline Pearson Chi-Square & 1.721 & 1 & 0.190 \\
\hline
\end{tabular}

5) Critical region:

Probability value $>$ significance level $(\alpha)$

6) Conclusion:

As our probability value is greater than level of significance so we accept null hypothesis $H_{o}$. On the basis of evidence, we may conclude that there is no association between the two variables.

\section{Question 5}

\begin{tabular}{lllll}
\hline What, according to you, will be the outcome if an older child is playing cricket with a young one? \\
\hline \multicolumn{4}{l}{ Count } & \multicolumn{3}{l}{ Gender } & Total \\
\cline { 2 - 4 } & & Male & Female & \\
\hline What, according to you, will be the outcome if an older & RNF & 6 & 7 & 13 \\
child is playing cricket with a young one? & NV & 30 & 27 & 57 \\
Total & & 36 & 34 & 70 \\
\hline
\end{tabular}




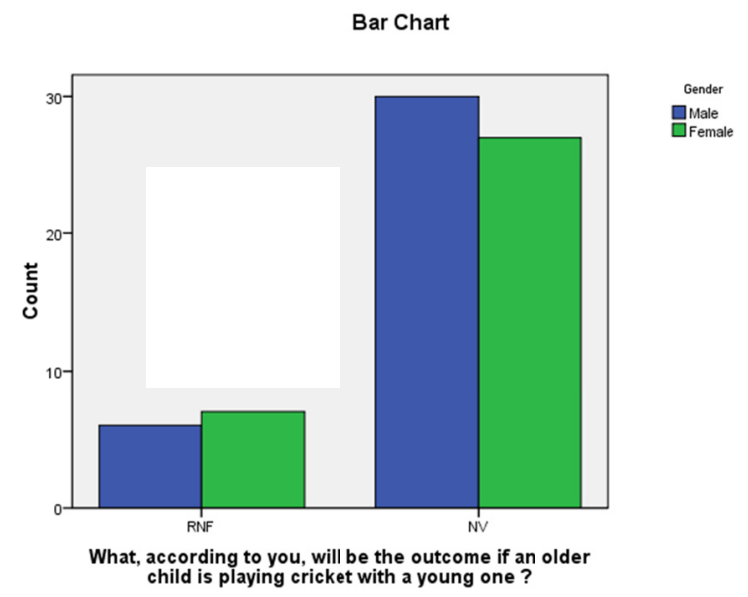

Figure 7. Bar chart shows the percentage of responses of both respondents (M/F)

1) $H_{o}=$ There is no association between the two variables.

$H_{1}=$ There is association between the two variables.

2) Level of significance: $\alpha=0.05$

3) Test Statistics:

$$
\chi^{2}=\sum_{i}^{r} \sum_{j}^{c} \frac{\left(o_{i j}-e_{i j}\right)^{2}}{e_{i j}}
$$

With degrees of freedom (r-1) (c-1)

4) Calculation:

$\chi^{2}=0.178$

\begin{tabular}{llll}
\hline & Value & df & Asymp. Sig. (2-sided) \\
\hline Pearson Chi-Square & 0.178 & 1 & 0.673 \\
\hline
\end{tabular}

5) Critical region:

Probability value $>$ significance level $(\alpha)$

6) Conclusion:

As our probability value is greater than level of significance, we are unable to reject our null hypothesis $H_{0}$ and may conclude that there is not sufficient evidence which show some association between the two variables.

Question 6

\begin{tabular}{lllll}
\hline What is more desirable with regard to the Quran? & \multicolumn{3}{l}{} \\
\hline Count & \multicolumn{3}{l}{ Tender } & \multicolumn{3}{l}{ Total } \\
\cline { 3 - 5 } & & Male & Female & \\
\hline What is more desirable with regard to the Quran? & RNF & 8 & 6 & 14 \\
& NV & 26 & 27 & 53 \\
Total & & 34 & 33 & 67 \\
\hline
\end{tabular}




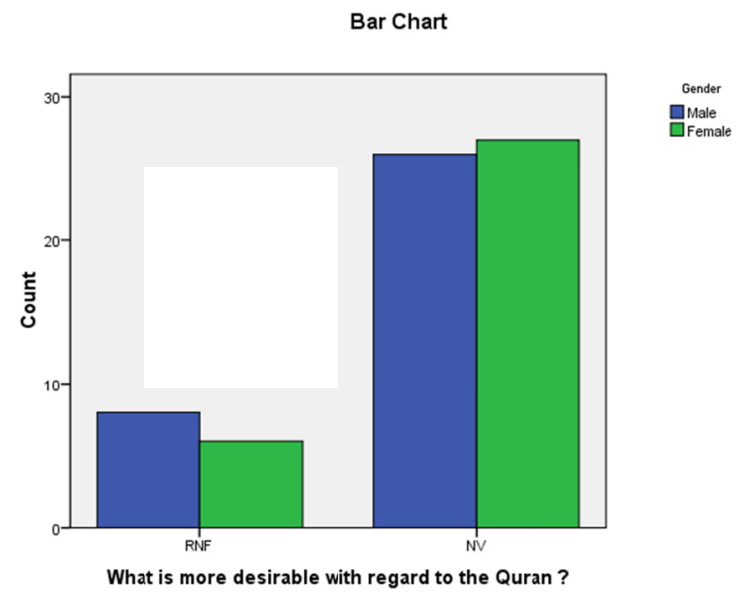

Figure 8. Bar chart shows the percentage of responses of both respondents (M/F)

1) $H_{o}=$ There is no association between the two variables.

$H_{1}=$ There is association between the two variables.

2) Level of significance: $\alpha=0.05$

3) Test Statistics:

$$
\chi^{2}=\sum_{i}^{r} \sum_{j}^{c} \frac{\left(o_{i j}-e_{i j}\right)^{2}}{e_{i j}}
$$

With degrees of freedom (r-1) (c-1)

4) Calculation:

$\chi^{2}=0.290$

\begin{tabular}{llll}
\hline & Value & df & Asymp. Sig. (2-sided) \\
\hline Pearson Chi-Square & 0.290 & 1 & 0.590 \\
\hline
\end{tabular}

5) Critical region:

Probability value $>$ significance level $(\alpha)$

6) Conclusion:

As our probability value is greater than level of significance, we are unable to reject our null hypothesis $H_{0}$ and may conclude that there is not sufficient evidence which show some association between the two variables.

Question 7

\begin{tabular}{|c|c|c|c|c|}
\hline Crosstab & & & & \\
\hline \multicolumn{5}{|l|}{ Count } \\
\hline & & \multicolumn{2}{|c|}{ Gender } & \multirow[t]{2}{*}{ Total } \\
\hline & & Male & Female & \\
\hline \multirow[t]{2}{*}{ What do you say on hearing the sound of a drum? } & RNF & 12 & 10 & 22 \\
\hline & NV & 24 & 25 & 49 \\
\hline Total & & 36 & 35 & 71 \\
\hline
\end{tabular}




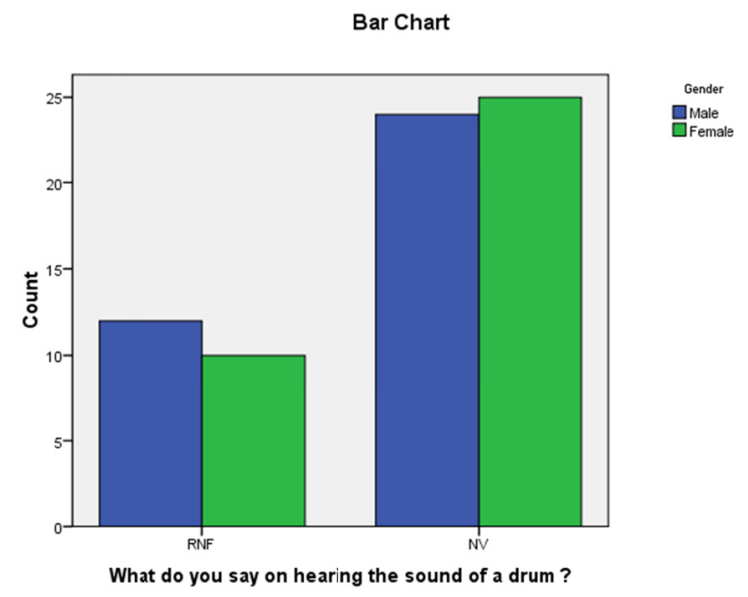

Figure 9. Bar chart shows the percentage of responses of both respondents (M/F)

1) $H_{o}=$ There is no association between the two variables.

$H_{1}=$ There is association between the two variables.

2) Level of significance: $\alpha=0.05$

3) Test Statistics:

$$
\chi^{2}=\sum_{i}^{r} \sum_{j}^{c} \frac{\left(o_{i j}-e_{i j}\right)^{2}}{e_{i j}}
$$

With degrees of freedom (r-1) (c-1)

4) Calculation:

$\chi^{2}=0.188$

\begin{tabular}{llll}
\hline & Value & df & Asymp. Sig. (2-sided) \\
\hline Pearson Chi-Square & 0.188 & 1 & 0.664 \\
\hline
\end{tabular}

5) Critical region:

Probability value $>$ significance level $(\alpha)$

6) Conclusion:

As our probability value is greater than level of significance, we are unable to reject our null hypothesis $H_{0}$ and may conclude that there is not sufficient evidence which show some association between the two variables.

Question 8

\begin{tabular}{lllll}
\hline Crosstab & & & & \\
\hline Count & & \multicolumn{2}{l}{ Gender } & \\
\cline { 2 - 4 } & & Male & Female & \\
\hline Which of these two are more favoured by the smokers? & RNF & 12 & 6 & 18 \\
& NV & 23 & 20 & 43 \\
Total & & 35 & 26 & 61 \\
\hline
\end{tabular}




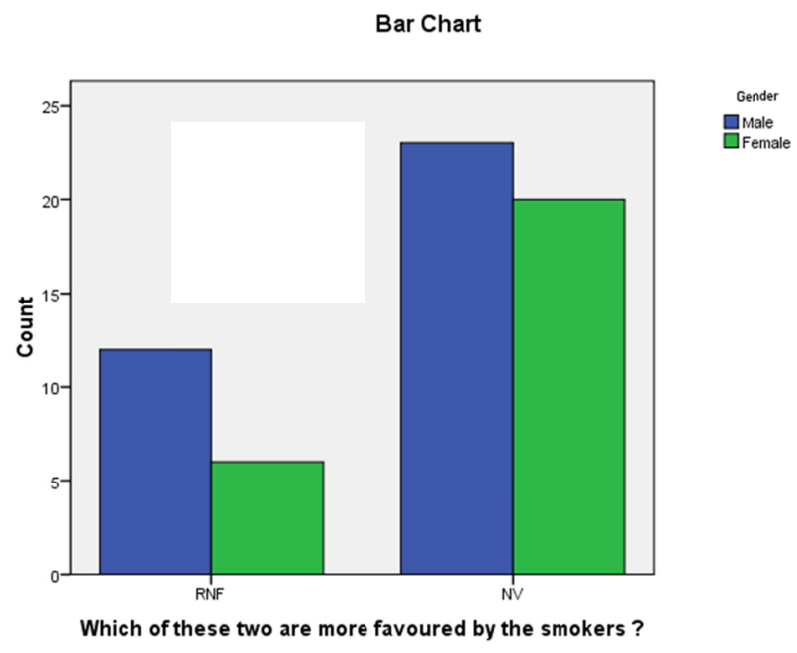

Figure 10. Bar chart shows the percentage of responses of both respondents $(\mathrm{M} / \mathrm{F})$

1) $H_{o}=$ There is no association between the two variables.

$H_{1}=$ There is association between the two variables.

2) Level of significance: $\alpha=0.05$

3) Test Statistics:

$$
\chi^{2}=\sum_{i}^{r} \sum_{j}^{c} \frac{\left(o_{i j}-e_{i j}\right)^{2}}{e_{i j}}
$$

With degrees of freedom (r-1) (c-1)

4) Calculation:

$\chi^{2}=0.901$

\begin{tabular}{llll}
\hline & Value & df & Asymp. Sig. (2-sided) \\
\hline Pearson Chi-Square & 0.901 & 1 & 0.343 \\
\hline
\end{tabular}

5) Critical region:

Probability value $>$ significance level $(\alpha)$

6) Conclusion:

As our probability value is greater than level of significance, we are unable to reject our null hypothesis $H_{0}$ and may conclude that there is not sufficient evidence to show some association between the two variables.

\begin{tabular}{lllll}
\hline Crosstab & & & \\
\hline Count & & \multicolumn{2}{l}{ Locality } & \multicolumn{2}{l}{ Total } \\
\cline { 2 - 4 } & & Urban & Non-Urban & \\
\hline Which of these two are more favoured by the smokers? & RNF & 2 & 16 & 18 \\
& NV & 29 & 14 & 43 \\
Total & & 31 & 30 & 61 \\
\hline
\end{tabular}




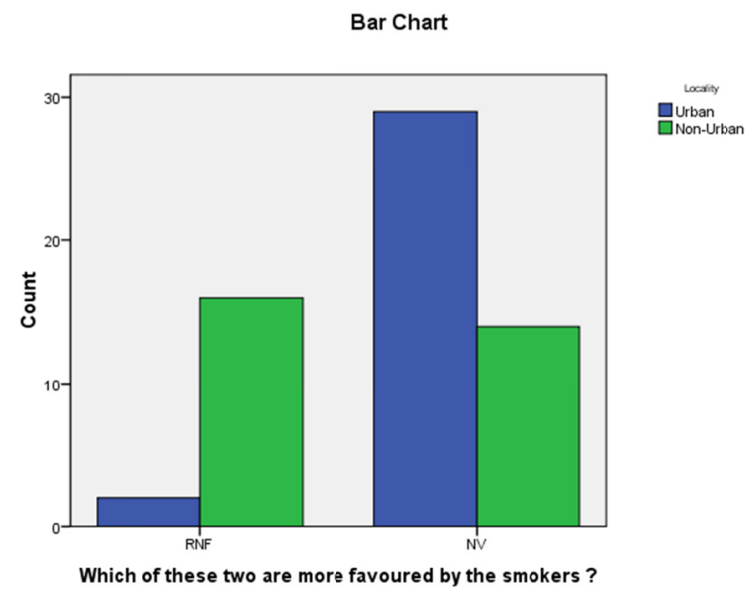

Figure 11. Bar chart shows the percentage of responses of both respondents $(\mathrm{M} / \mathrm{F})$

1) $H_{o}=$ There is no association between the two variables.

$H_{1}=$ There is association between the two variables.

2) Level of significance: $\alpha=0.05$

3) Test Statistics:

$$
\chi^{2}=\sum_{i}^{r} \sum_{j}^{c} \frac{\left(o_{i j}-e_{i j}\right)^{2}}{e_{i j}}
$$

With degrees of freedom (r-1) (c-1)

4) Calculation:

$\chi^{2}=16.109$

\begin{tabular}{llll}
\hline & Value & df & Asymp. Sig. (2-sided) \\
\hline Pearson Chi-Square & 16.109 & 1 & 0.000 \\
\hline
\end{tabular}

5) Critical region:

Probability value $\leqslant$ significance level $(\alpha)$

6) Conclusion:

As our probability value is less than level of significance our result is significant, so we are unable to accept our null hypothesis $H_{o}$ and may conclude that there is some association between the two variables.

Question 9

\begin{tabular}{|c|c|c|c|c|}
\hline \\
\hline \multicolumn{5}{|l|}{ Count } \\
\hline & & \multicolumn{2}{|c|}{ Gender } & \multirow[t]{2}{*}{ Total } \\
\hline & & Male & Female & \\
\hline \multirow[t]{2}{*}{ Which of these two are more favourite with citizens of Lahore? } & $\mathrm{RNF}$ & 5 & 2 & 7 \\
\hline & NV & 31 & 34 & 65 \\
\hline Total & & 36 & 36 & 72 \\
\hline
\end{tabular}




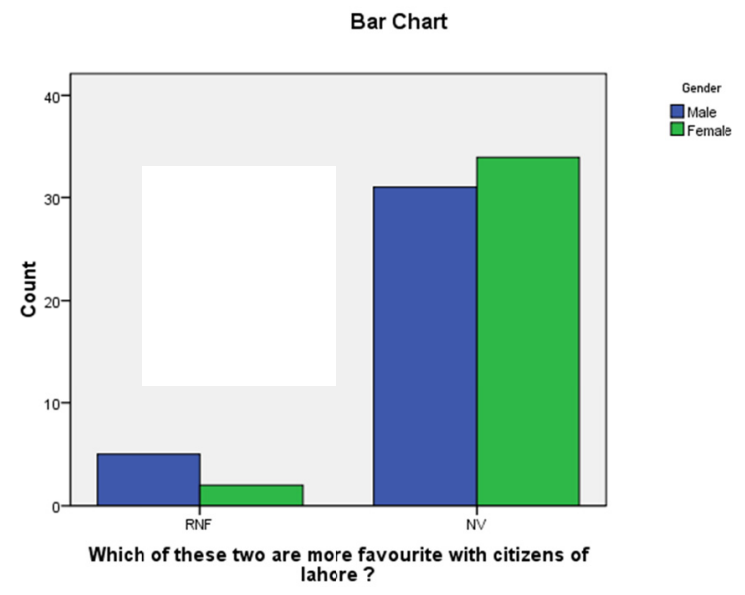

Figure 12. Bar chart shows the percentage of responses of both respondents $(\mathrm{M} / \mathrm{F})$

1) $H_{o}=$ There is no association between the two variables.

$H_{1}=$ There is association between the two variables.

2) Level of significance: $\alpha=0.05$

3) Test Statistics:

$$
\chi^{2}=\sum_{i}^{r} \sum_{j}^{c} \frac{\left(o_{i j}-e_{i j}\right)^{2}}{e_{i j}}
$$

With degrees of freedom (r-1) (c-1)

4) Calculation:

$\chi^{2}=1.424$

\begin{tabular}{llll}
\hline & Value & df & Asymp. Sig. (2-sided) \\
\hline Pearson Chi-Square & 1.424 & 1 & 0.233 \\
\hline
\end{tabular}

5) Critical region:

Probability value $>$ significance level $(\alpha)$

6) Conclusion:

As our probability value is greater than level of significance, we are unable to reject our null hypothesis $H_{0}$ and may conclude that there.

Question 10

\begin{tabular}{lllll}
\hline Crosstab & & & & \\
\hline Count & & \multicolumn{2}{l}{ Gender } & \\
\cline { 3 - 4 } & & Male & Female & \\
\hline Who can eat more over-baked bread? & RNF & 5 & 1 & 6 \\
& NV & 28 & 33 & 61 \\
Total & & 33 & 34 & 67 \\
\hline
\end{tabular}




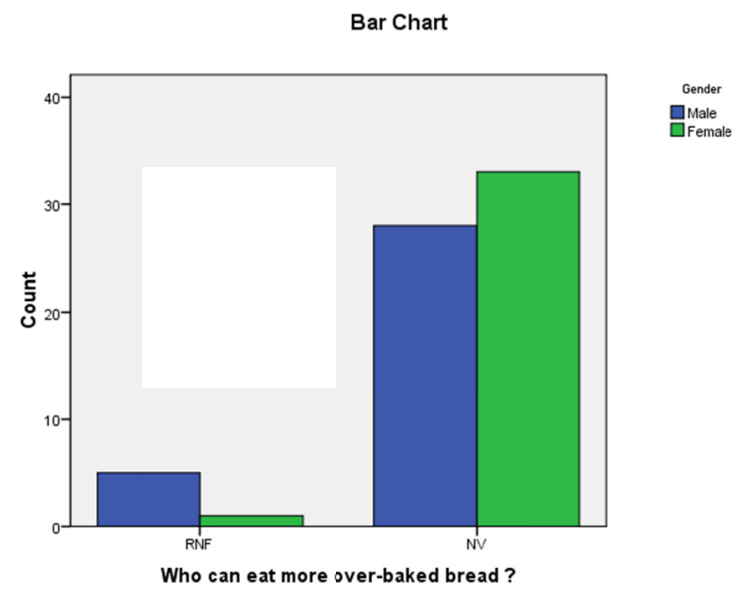

Figure 13. Bar chart shows the percentage of responses of both respondents $(\mathrm{M} / \mathrm{F})$

1) $H_{o}=$ There is no association between the two variables.

$H_{1}=$ There is association between the two variables.

2) Level of significance: $\alpha=0.05$

3) Test Statistics:

$$
\chi^{2}=\sum_{i}^{r} \sum_{j}^{c} \frac{\left(o_{i j}-e_{i j}\right)^{2}}{e_{i j}}
$$

With degrees of freedom (r-1) (c-1)

4) Calculation:

$\chi^{2}=3.062$

\begin{tabular}{llll}
\hline & Value & df & Asymp. Sig. (2-sided) \\
\hline Pearson Chi-Square & 3.062 & 1 & 0.080 \\
\hline
\end{tabular}

5) Critical region:

Probability value $>$ significance level $(\alpha)$

6) Conclusion:

As our probability value is greater than level of significance, we are unable to reject our null hypothesis $H_{0}$ and may conclude that there is not sufficient evidence to show some association between the two variables.

\section{Results and Findings}

\subsection{Synthesis of Results}

Statistical analysis of the data collected in the structured interviews stage revealed significant differences among different social groups residing in Lahore. There are statistically significant differences in these samples. This led to the intermediate conclusion that if this is the case, any differences in language use will be based on social hierarchy of the participants.

There were two main areas of focus in this study: first that the variable (n) is a social differentiator between male and female; and second, to know the generalizability of Labovian sociolinguistics. There are some factors where the results of present research significantly match with Labovian research in New York City.

\subsection{Interview Analysis}

Significant gender differences within the interview data emerge from the regional, social, age and educational, analyses. Gender differences between speakers across regions have been found in the pre-vocalic $/ \mathrm{n} /$ environments. In addition, a significant difference has been found according to regional background in the prevocalic environment. The pre-consonantal environments have shown no significant interactions with social or educational factors within the distributions according to sex. 


\subsection{The Gender Factor}

The results do not show any kind of linguistic differences of men and women. On the contrary, Labov (1990, p. 205) presents the most consistent results about the linguistic differences of men and women. In this context, as for as the present variants are concerned, there is no sociolinguistic stratification between men and women in Lahore. In this way, a sexual pattern of differentiation does not emerge, which is found in Western ideology that females are more prone to prestige pattern than males.

\section{Conclusion}

The aim of this thesis was to look closely into the variants $/ \mathrm{n} /$ and $/ \tilde{\mathrm{f}} /$ gender differentiators in the speech community.

The following brief conclusions were formulated on the basis of the finding of this study:

\subsection{Gender Differences}

There is no sociolinguistic stratification between men and women in Lahore, as for as $/ \tilde{\mathfrak{t}} /$ is concerned. The results do not show any kind of linguistic differences of men and women. On the contrary, Labov (1990, p. 205) presents the most consistent results about the linguistic differences of men and women. In this context, as for as the present variants are concerned, there is no sociolinguistic stratification between men and women in Lahore. In this way, a sexual pattern of differentiation does not emerge, which is found in Western linguistic ideology that females are more prone to prestige pattern than males.

\section{References}

Ash, S. (2002). Social class. In J. Chambers, P. Trudgill \& N. Schilling-Estes (Eds.), The handbook of language variation and change (pp. 402-422). Oxford: Blackwell https://doi.org/10.1111/b.9781405116923.2003.00023.x

Barbara, J. (2009). Language in society (pp. 280-281). Cambridge University Press.

Campbell, K. (2009). The nature of sociolinguistic perception. Language Variation and Change, 21(1), 135-156. https://doi.org/10.1017/S0954394509000052

Census. (1998). District Census Report, Lahore (DCR-2000). Population Census Organization, Statistics Division, Govt. of Pakistan. $\quad$ Retrieved from http://en.wikipedia.org/wiki/Demographics_of_Pakistan\#Punjabi

Department of Punjabi University. (2017). Patiala, India, Punjabi Khoj. Retrieved December 23, 2017, from http://www.learnpunjabi.org/intro1.asp

Dittmar. (1997). Extending the concept of the (socio) linguistic variable to sla (pp. 57, 534). Retrieved December 23, 2017, from http://pdfcast.org/.../extending-the-concept-of-the-socio-linguistic-variable-to sla

Eckert, P. (1997). Age as a sociolinguistic variable. In F. Coulmas (Ed.), Handbook of sociolinguistics (pp. 151167). Oxford: Blackwell. https://doi.org/10.1002/9781405166256.ch9

Encyclopedia Britannica Deluxe. (2000). Retrieved on November 25, 2011, from http://www.amazon.com/...Encyclopedia-Britannica-Deluxe/.../B00002DF0V

Fasold, R. W. (1990). Introduction to sociolinguistics: The sociolinguistics of society. Retrieved December 23, 2011, from http://books.google.com/books/about/Introduction_to_sociolinguistics.html?id

Ferguson, C. A. (1959). "Diglossia”. Word, 15, 325-340. https://doi.org/10.1080/00437956.1959.11659702

Fischer. (1958). Variation and Language, an Overview in Encyclopedia of Language. Retrieved December 23, 2011, from http://www.ncsu.edu/linguistics/docs/pdfs/walt/Language_variation-sgl.pdf

Giles, H. (1979). Ethnicity markers in speech. In K. R. Scherer \& H. Giles (Eds), Social markers in speech (pp. 251-290). Cambridge University Press.

Gumperz. (1992). Sociolinguistic Variables. Retrieved December 23, 2011, from http://www.criticism.com/linguistics/sociolinguistic-variable.php

Haeri, N. (1997). Language Ideologies in the Arabic Diglossia of Egypt. New York: Kegan Paul International.

Hoijer, H. (1964). Cultural implications of some Navaho linguistic categories. In H. Del (Ed.), Language in Culture and society: A Reader in Linguistics and Anthropology. New York: harper and Row.

Hymes, D. (1974). Foundations in Sociolinguistics: An Ethnographic Approach. Philadelphia: University of Pennsylvania Press. 
Karamat, N. (2002, May 15). Phonemic Inventory of Punjabi. Akhbar-i-Urdu. Retrieved April 25, 2017 from http://www.crulp.org/Publication/Crulp_report/CR02_21E.pdf

Kerswill, P. E., \& Wright, S. (1990). On the limits of auditory transcription: A socio-phonetic Perspective. Language Variation and Change, 2, 255-275. https://doi.org/10.1017/S0954394500000363

Labov, W. (1972). Sociolinguistic Patterns. Philadelphia, PA: University of Pennsylvania Press.

Labov, W. (1990). The intersection of sex and social class in the course of linguistic change. Language Variation and Change, 2, 205-254. https://doi.org/10.1017/S0954394500000338

Labov, W. (1994). Internal factors. Principles of Linguistic Changes, 1.

Labov, W. (2006). The Social Stratification of English in New York City. Cambridge, U.K.: Cambridge University Press. https://doi.org/10.1017/CBO9780511618208

Ladefoged, \& Maddison. (1996). The Sounds of the World's Languages. Blackwell Publishers. Retrieved November 25, 2017 from http://www.en.wikipedia.org/wiki/Flap_consonant

Le Page, R. B., \& Tabouret-Keller, A. (1985). Act of Identity. Cambridge: Cambridge University Press.

Levon. (2006, 2007). Explaining gay-sounding voices: Trends, insights, and future. Retrieved December 23, 2011, from http://prezi.com/.../explaining-gay-sounding-voices-trends-insights-and-future directions

Louis, G. (1905). Dialectology. Retrieved December 23, 2017 from http://www.learning.londonmet.ac.uk/languages/k1250/sectionE/networks

\section{Copyrights}

Copyright for this article is retained by the author, with first publication rights granted to the journal.

This is an open-access article distributed under the terms and conditions of the Creative Commons Attribution license (http://creativecommons.org/licenses/by/4.0/). 